\title{
快適性の構造に関する基礎的研究 FUNDAMENTAL STUDY ON THE STRUCTURE OF COMFORT AND PLEASANTNESS
}

\author{
瀬尾文彰*, 坊垣和明** \\ Humiaki SEO and Kazuaki BOGAKI
}

\begin{abstract}
Comfort is one of the most important keywords on research and development of environment or environmental technologies. But, the concept of comfort is not confirmed, and it seems that the meanings of comfort or pleasantness is not recognized correctly. The purpose of this research is to comfirm the concept of comfort, and to propose the structure of comfort and pleasantness. Examining the concept of comfort in the various research field of architecture, town planning and psychology, the levels of comfort and pleasantness were sorted and arranged into 6 stages based on the up-to-date informations of the neurophysiology. These. 6 stages are expressed using general words "comfort" and "discomfot", and consist of 4 levels of "comfort" and 2 levels of "discomfort". In this paper, the third level of "comfot" which is the most important level for human beings is emphasized and the limits of technologies for comfort and pleasantness are also described.
\end{abstract}

Keywords : comfort, pleasantness, pleasure, neurophysiology, homeostasis 快適、快感、快楽、神経生理学、ホメオスタシス

\section{1.はじめに}

高度消費社会の中で、「快適」は「イメージ」「感性」 なとと共に流行語の一つとなり、重要な技術開発課題と あされた。安定社会への移行期に入ると、「快適」は 「ゆとり」「こころ」なとと横並びに用いられ、技術開 発や都市・建築計画のテーマとしてますます重要性を增 しつつある。そのため、快適条件の明確化や測定方法に 関するニーズには極めて高いものがあるが、問題が人間 の奥深い感情にかかわるむのであるだけに、従来の研究 は、これに対する充分な解答を与えるには至っていない。 そ屯そも、快適とは何であるかという定義に関して諸 説立ち並び、定説が定まらぬというのが、快適研究の現 状であるように思われる。注い

そうしたなかで、「消極的快適」「積極的快適」のレ ベル分けを設ける必要があるというところまでは、大方 の同意が得られているように見受けられるが、それぞれ の内容に関する見解は異なり、かつ瞹昧な印象をまぬが れない。注21
快適を安定的、静的、平衡的な状態にとどめることな く、ダイナミックな生命の状態としても捉えてゆくこと が重要であるとする視点は、人間の生きがいが問われる 今日にあっては当然のものと言える。それだけに、快適 の静的状態（通称「消極的快適」）とダイナミックな状 態（通称「積極的快適」）に関する考察を一段と深め、 両者の境界がとこにあり、それぞれをどう定義するかと いった問題をつきつめることは、今後の快適研究の上で 欠かせない課題だと思われる。

本研究は、神経生理学の最近の知見を拠り所として、 快適性の構造を明らかにし、今後の快適研究ならびに快 適関連技術開発に対して一定の枠組を提示することを目 的とする。

\section{2. 快・不快の原理}

\section{（1）快・不快の神経生理}

環境への適応や生命維持のために営まれる生体のホメ
* 大同工業大学建設工学科 教授・工博 (元建築研究所部長)

** 建設省建築研究所 室長
Prof., Dept. of Construction, Faculty of Engineering, Daido Institute of Technology, Dr. Eng.

Building Research Institute, Ministry of Construction 
オスタシズ主3)には、暑い時の発汗といった自律的な生 体反応の調節のほかに、情動を介して警告を発し、ある いは誘導して行動を变化させる、行動介在型の仕組みが 含まれている。 「不快」に感じる時に、空を開けるとさわやかな風が入 って「快適」に感じるといったケースでは、「暑さ＝不 快」というムチと「さわやか=快適」というアメによっ て、人をして窓を開ける行動へと促すという形で、温度 状態を生存に適する状態に保つためのホメオスタシス機 構が働いているのだと考えられる。5181

このように、ホメオスタシス機構を働かせるためのプ ラス側及びマイナス側の作動要因として、快・不快を位 置つける考え方は、快適に関する考察への入り口として 妥当なものと思われるが、考察をさらに先に進めるため には、神経系におけるどのような現象によって、これが 制御されているのかを検討しておく必要がある。

神経系は無数の神経細胞（ニューロン）から成り、二 ユーロンはシナプスと呼ばれる特殊な接合部におけるシ ナプス伝達物質の授受によって情報の伝播を行っている。 シナプス伝達物質には様々のものがあり、特定の伝達物 質を用いるニューロンは、脳の中で各々に固有の伝達経 路を形成する傾向がある。 ${ }^{91}$ 快・不快の情報回路につい ていうと、大脳皮質のうち大脳边縁系とのかかわりが深 く、この領域に分布するモノアミン類（ドーパミン等） や、オピオイドペプチド類 (エンケファリン等) をシナ プス伝達物質とする神経回路が、快・不快反応を発生さ

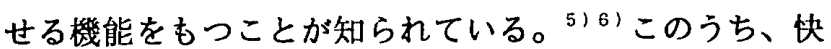
の神経回路は「報酬系」と呼ばれ、不快の神経回路は

「罰系」と呼ばれ、その所在を電気刺激て確認する多く の動物実験がなされている。法41

ホメオスタシスとの関係でみると、動物には、生存や 適応に希ましい条件のもとでは快（報酬）系のニューロ ンが刺激され、逆に希ましくない条件によっては不快

(罚) 系のニューロンが刺激されるという生理的な仕組 が具わっているものと考えられている。5181

(2) 人間的な快·不快

しかしながら、人間の快・不快は上記のホメオスタシ スの範囲を逸脱している。人間の場合には、精神的な満 足という高度で抽象的な条件によってもたらされる快が あり、また逆に不快もある。これらは通常のホメオスタ シスと同じには考えにくいが、神経系の現象としては同 様に考えられる。すなわち、精神的な条件によってあ、 上記のような生理的な仕組みが作動するという絶妙の構 造化か人間の脳内にはかられているものと考えられ、5) ここに、快適問題を解き明かすための重要な根拠を見出 すことができる。

人間の場合の快・不快には、辺緑系の関与する原始感 情に、新皮貿からの知的・情的判断が統合され、複雑な
過程を経て生じるケースが多いところに特徵があるのだ と言われる。 ${ }^{81}$ 自律的なホメオスタシスは、脳幹（視床 下部）で処理され、行動介在型の動物的なホメオスタシ スは大脳辺縁系で処理される。一方、人間的な快・不快 には新皮質が深く関与しており、人が成長する間に次第 に条件つけられたり、学習されたりした新皮質からの刺 激が、辺緑系に投影されて生じるケースが多い。すなわ ち、人間的な快・不快の具体化のためには、洒值的な認 識や、事態に対する予測や期待という高次の新皮質系の 評価が必要になると言われており、この種の評価は、個 人的・文化的に学習された後天性の基準に基づいてなさ れる。 ${ }^{81}$

\section{（３）シンボル型の刺激}

人は美しいものに快感をおぼえるが、何をもって美し いとするかの基準は生得的に人間に具わっているとは考 えにくい面が多い。不快（嫌悪、悲しみ、憎悪、絶望の ような人間的不快）についても類似の現象が見られる。 それにもかかわらず快・不快の情動がもたらされるから には、そこに快・不快の中权が刺激されるという現象が 存在している筈である。その場合の刺激は感覚刺激その ものではなしに、感覚刺激のパターンに対する後天的

（私的・文化的）な意味づけが効果をむたらすと考えら れる。注51 その点で、通常のホメオスタシス的な快・不 快と異なっている。

そのことから、快・不快をむたらす刺激には、熱・光 量・音波・力学刺激等の感覚刺激と、そのパターンから くる意味刺激とがあると考えられる。ここでは、前者 （生体に直接反応を強いる生得的な感覚刺激）をシグナ ル型の刺激と呼び、後者（後天的な反応形態をもたらす 感覚刺激のパターン) をシンボル型の刺激と呼ぶ。注61

「座りにくい」「座り心地よい」椅子はシグナル系の 快・不快の刺激に由来するが、「美しかったり堂々とし ていて座ることに心踊る」椅子はシンボル系の快刺激に 基つく。この部屋の温熱環境の快・不快はシグナル系だ が、テザインによるこの部屋の快・不快はシンボル系で ある。心地よい色彩は多くの場合にシグナル系と考えら れるが、影られた絵画の良し悪しはシンボル系である。 飢えたときの食物、冷えたときの湯、筋肉疲労時のマッ サーシ、等が快をもたらすのはシグナル系の刺激による と基本的には言える。しかし、それがなにかを成し遂げ た後の満足感と共にあるときには、シンボル系の快と混 在していることになりそうである。達成感というのは人 間的な価値意識だからである。

シンボル型の刺激か、ととのように情動をもたらすのか、 その生理的仕組みは極めて複雑だと察せられる。詳細は 明らかではないが、なんらかの仕方で関連のニューロン に刺激を与え、シナプス伝達物質の放散を促す仕組みが

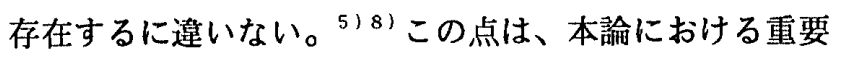


な立脚点の一つである。

従来、快適性のレベル分けの一つとして生理的快適 · 心理的快適を用い、これを生理現象と心理現象に帰する 考え方があったが、注へこの考え方は瞹昧であり、シグ ナル型、シンボル型という考え方により、従来の生理的 快適・心理的快適を刺激の型の違いに還元し、脳内現象 としては共に快・不快系のシナプス伝達物質の放散であ るとする一元的な捉え方ができるようになる。

\section{（4）「積極的快適」}

ここまでの文中で快・不快というときの快は、神経生 理現象的にはドーパミン等の伝達物質が活性化している 状熊を指している。一方、不快のない（不快伝達物質の 分泌のない、当然、快伝達物質の分泌もない) 平衡状態 を指して快適状態とされることが、日常的には少なから ず認められる。「騒音を除去して環境を快適にする」な どがそれである。これは前記の「消極的快適」に相当す る。一方、神経生理学的な快状態は、「積極的快適」に 対応すると考えられる。

ところで、その積極的な神経生理学的な快状態のうち にも、少なくとも2つのレベルを区别する必要があると 思われる。1つは、快がホメオスタシスにおける報酬と してもたらされるレベルである。2つ目に、ホメオスタ シスとは別に単に楽しみのためだけに追求される快領域 というものが存在する。いここの種の快には、通常、稳 やかな幸福感とは異質の烈しさが伴う。ランニングハイ と呼ばれる快感、ジェットコースターのスリル感、興奮 が全身を通り抜けるような音楽、等々…。 また、創造 の喜びや苦難の末の達成感などもそうであろう。これら のことは生命維持や種の保存とは関係がない。関係がな い灷ころか、人間はこの種の喜びのために、敢えて生命 を危険にさらすことすらある。冬山登山の儀牲者が後を 断たないのもそれだし、身を投げうって㓣造の偉業にと り組む偉人の逸話にもそれが認められる。18)191

\section{（5）「快楽」「悦楽」}

通常のホメオスタシスにおける報酬の域を越え、楽し みや喜びのためだけの快追求という人間には極めて頻繁 に認められるこの現象を、ここでは「快楽」ないし「悦 楽」注81 と呼ぶことにする。エンケファリンを伀達物質 とする神経回路は、軽い痛みを伴う刺激作用から生じる 快感に関係しているという説がある。91211「快楽」

「悦楽」は、神経生理学的にはエンケファリンと関係が あるとも考えられるが定かではない。

いずれにせよ、「快楽」「悦楽」における快追求の激 しさ、執执さから察するに、伝達物質の放散の度合いは かなり激しい場合があるのではないか。たとえば電極で 快中枢を強制的に刺激されるネズミは死に至る快の追求 に追い立てられる注4) が、自然状態の動物にはこのよう なことはなく、一定の節度の範囲で解除される。ホメオ
スタシス報酬系だからである。それに対して、人間の

「快楽」「悦楽」追求においては、強迫的にペダルを踏 み続けるネズミさながらの状態に自らを陥れることも少 なくない。寝食を忘れた創造活動への没入や情熱的な性 的活動、あるいは過剩な消費活動なとににその例を見るこ とができる。

\section{（6）精神的機能の維持}

「快楽」「悦楽」の追求は通常のホメオスタシスとは 異なるか、別の観点から、人間に特有の精神の働きを維 持・育成する機能の一種であるとする考え方も成り立つ。

人間の脳には、2つの統合系がある ${ }^{8)}$ が、そのうち大 脳新皮質は意志 - 創造・思考・高度な感情などをつかさ とり、大脳辺縁系は人間が生物としてたくましく生きる ために必要な意欲・感情・欲望などの原始的意識をつか さとる。両者は、相互に訨存しバランスをとり合ってい る状態にあることが希ましい。ところが、高度な文明を 生きる人間にあっては、新皮質系の理性によって辺緑系 の本能が抑圧された状態になりがちである。そのため、 生命力の活性化を図り人間らしさを維持するために辺縁 系の本能を解放するという観点から「快楽」「悦楽」の 意味を理解することが可能である。それはつまり、新皮 質と辺縁系の両機能に基つく人間の精神を活性化せしめ ることである。

高度な脳を有することがそもそも人間の本来であると すれば、その精神的活力を高揚せしめる「快楽」「悦楽」 が、生体維持のためのホメオスタシスとレベルは違うと しても、精神活力の維持・向上のためのアメであるとい う解釈は成り立つ。名誉欲・金銭欲・優越感の充足なと、 あまり碓められたものとは言えない「快楽」すらも、人 間の自己向上に役立つ場合が少なくはないのである。

\section{（7）破壊型快楽}

自らを破㓕に陷れるほどの「快楽」追求の極端な例と しては、薬物なとにによる耽溺現象が挙げられる。しかし ながら、薬物などによる「快楽」は、伝達物質の放散に よるものではない。快中枢のシナプスにおける受容体が、 本来の伝達物質とよく似た構造をもつモルヒネ、へロイ ン、コカインのような物質を受け入れてしまうことによ り、快中枢の興奮状態が引き起こされる。つまり、偽の 合鍵で快感の屝が開かれてしまう。そのために、電極で 刺激されるネズミとまったく同じ原理によって、無益に 身をすり減らすだけの快の道求に陌るというのが、この 種の「快楽」の実態であり、精神機能維持の「快楽」と は明確に区別する必要がある。

\section{3. 快適性の構造}

前記から、快・不快の主たる区分を次のように示せる。 ○不快（罰系神経回路の刺激） 


\section{○平衡·安定}

○快（報酬系神経回路の刺激）

○楽しみのための快 $=$ 快楽・悦楽

この区分を基に、自己破壊型の「快楽」、精神性の強 い不快の領域（憎恶・絶望なと）、シグナル型刺激・シ ンボル型刺激、などの観点を加味して、快・不快の様々 な水準を一覧できるように取りまとめたのが表 1 である。

この表の特徴のひとつは、快・不快の諸水準を「快適」 及び「不快」のレベルとして統一的に標記している点に ある。昨今の快適性ばやりの傾向のなかで、ここでいう 諸水準がまぜこぜに論ぜられたり、故意ないし無意識に 特定の水準に限定して取り扱われる弊害も少なくない。 そこで、議論を明快にするために、用語の一般性を考慮 して「快適」「不快」で統一した上、「快適」「不快」 のうちに様々のレベルがあるという表現が便利と考え、 この標記方法をとった。あわせて通称としての呼び名、 さらに神経生理現象との関係を併記した。これをもって、 快適性の構造に関する本論における提案とする。

以下、各レベルについて、捕捉すべき点を記す。

の不快レベル 1

与えられた刺激に対して自律機能のみで対応しきれず、 罰系神経回路が活性化し、刺激を除去する行動を促され る状態。行動によって刺激が除去され、ただちに安定状 態に帰するなら、ホメオスタシスが正常に働いているの であって問題はない。部屋が暑いと感じたときに、空の 開閉によって熱的刺激を即座に適正化できる場合がこれ に当たる。このような場合には、事実上「不快」の問題 は生じないと言ってよい。空が開かなかったり空調のコ ントロールが効かなかったりして、刺激状態を改善でき ない状態であると、これが「不快レベル1」「苦痛」と して顕在化してくる。

これは生体が正常に維持されがたい危険を知らせるホ メオスタシスの警告であるから、通常、人はこの状況を
脱することを希み、苦悩する。シグナル型刺激に限れば、 このことは、動物一般に共通している。人間において異 なるのは、人間はこの状態を覸雲に避けようとするだけ ではなしに、時には逆にこれを変化や刺激として意図的 に活用することを選び、「快適」への転化を企図する場 合のある点だが、詳しくは後に述へる。

シンボル型の例としては、室内のしつらえが乱雑で心 地よさややすらきが感じられない場合注91や、後述の高層

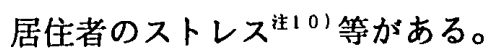

\section{の不快レペル 2}

「不快レペル1」は動物に共通のホメオスタシス現象 である。それに対して人間は、脳の発達が高度なだけに、 恐らくは他の動物にはあまりないと思われる特異な不快 をも経験しなければならない。注いそれは肉体に対する 脅威というょりは精神への脅威である。すなわち、憎恶、 嫌悪、脄妬、悲嘆、絶望なとといった様々な精神的不快 を免れないのが人間という生き物である。これには、文 化や学習に基つく高度で相対的な価值判断が深く関係し ている。

\section{○快適レペル 1}

刺激が自律機能のみで処理され、神経回路は報酬系、 罰系いずれも作動することのない平衡・安定の状態。

「快適レベル2」との対比で消極的快適とも呼ばれる。 動物の例でいえば、草原のライオンが獲物にありつい て満ち足りた面持ちで身を横たえているのがこの状態。 時が経って空腹という不快が訪れると、新たな獲物を求 めて狩りに出かけ、空腹をいやし舌つつみを打つという 快感（快適レベル2）を経験したのち、再び平衡・安定 のやすらぎの状態に入っていく。動物は一般に「不快レ ベル1」と「快適レベル2」の振幅の間で「快適レベル $1 」$ (シグナル型の) を求めつつ生きていると考えてよ い。5111 同じモデルで人間を考えてしまうと、「快適 レペル1」を過大視し過ぎ、間に対する見方が単純に

表 1 快・不快の構造

\begin{tabular}{|c|c|c|c|c|c|c|}
\hline & \multicolumn{3}{|c|}{ 生体機能維持のための快 - 不快 } & \multicolumn{3}{|c|}{ 精神的な块・不块 } \\
\hline & 不块レペル 1 & 快適レペル 1 & 快過レベル 2 & 快適レペル 3 & 快適レベル 4 & 不快レヘル 2 \\
\hline & \multirow[b]{2}{*}{$\begin{array}{l}\text { 苦痛 } \\
\text { (ホメオスタシス跒系) }\end{array}$} & \multirow[b]{2}{*}{$\begin{array}{l}\text { やすらき Confort } \\
\text { (ホメオスタシス平街) }\end{array}$} & \multirow[b]{2}{*}{$\begin{array}{l}\text { 块盛 Pleasantness } \\
\text { (ホメオスタシス跟酬系) }\end{array}$} & \multicolumn{2}{|c|}{ （祭みのための快） } & \multirow[b]{2}{*}{$\begin{array}{l}\text { 娭要 } \\
\text { (欧快楽) }\end{array}$} \\
\hline & & & & $\begin{array}{c}\text { 快楽・说楽 Pleasure } \\
\text { (尉神維持型块楽) }\end{array}$ & 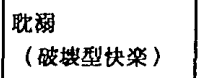 & \\
\hline 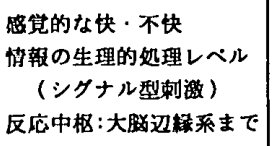 & 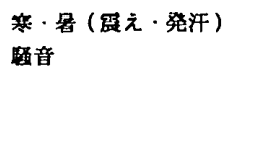 & 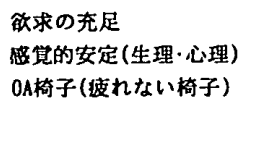 & 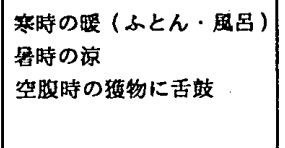 & 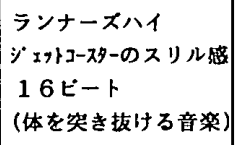 & $\mid \begin{array}{l}\text { ドラック } \\
\text { (聚物による耽湖) }\end{array}$ & \\
\hline 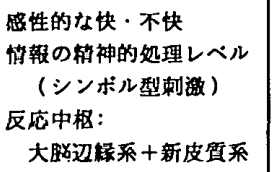 & $\begin{array}{l}\text { 不渵・久損感 } \\
\text { 心地好さの感しられない } \\
\text { 乱維な部屋 } \\
\text { 商風住宅居住者の } \\
\text { ストレス }\end{array}$ & $\begin{array}{l}\text { 感性的安定 } \\
ア メ ニ テ 1 ~\end{array}$ & 不满解消 & 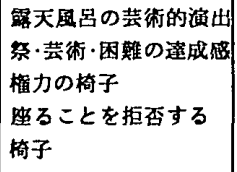 & 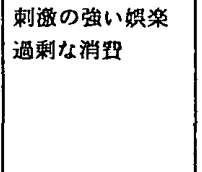 & 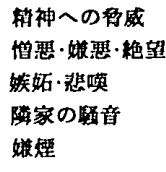 \\
\hline
\end{tabular}


すぎるという誤りに陥る。従来、環境工学の快適性や都 市計画のアメニティの概念は、このレベルにとどまる場 合が多いのではなかったか。反省を要するところである。

もちろん、安定や落ち着き・やすらきは重要なことだ が、それだけでは精神としての人間が満足しない。単調 で退屈だと感じ、逆にそれを苦痛と感じる場合すらある のだから、このレベルだけで人間の快適を語り尽くすこ とはできない。こうした認識は今日では一般化しつつあ り、2８８２1＼cjkstart快適問題の力点は「上位の快適とは何か」 に移りつつあると考えてよい。

しかし、このレベル、つまり不快でないことが、いま だに極めて重要な意味を有する分野があることも忘れる 訳にゆかない。例えばO A 椅子は、座ることから快感が 得られる（安楽椅子や権力を象徵する椅子のように）必 要はないが、不快であってはいけない。身体への負荷を 最小化する必要がある。建築の例では、高層住宅の居住 者が様々なストレスにさらされているという報告がある。 注10)この場合には居住者は日常的に不快状態にあるわけ

で、それを排除し「快適レベル1」への改善が急がれる。 の快適レベル 2

刺激に対して行動的な対応がとられ、報酬系の神経回 路がまさに刺激されつつある状態。たとえば、渴きのと きの水のうまさがこれに当たる。注121

O A 椅子で「快適レベル1」が重要なのは、もともと 無理な姿勢を長時間強いる仕事の性格による。それに対 して、楽な姿勢をとるのが目的の安楽椅子では、不快の ないのが当たり前だから、むしろそれ以上を求められる。 つまり快感であり、神経生理的にはドーパミン系の伝達 物質がドッと放出されるような状態である。しかし、実 際にはなかなかそれほとの椅子はない。大方は「快適レ ベル1」を保証してくれるくらいがせいぜいである。と ころがそうした亚みの安楽椅子といえども、時と事情に よっては顕著な快感の椅子に変じることがある。OA椅 子の永い勤務に疲れた体を横たえる目舞間などがそれであ る。そのとき、紛れもなくドーパミン系物質が放出され、 快感が体を走る。疲れた体を自然な楽な姿勢に帰したい とする欲求が解放された結果としての、ホメオスタシス 現象である。すなわち、「快適レベル2」が生じたのだ と考えられる。

「快適レベル2」はホメオスタシスの報酬として得ら

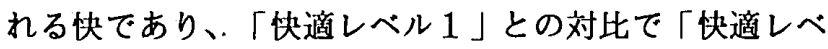
ル3」ともとも積極的快適と呼ばれることがある。

○快適レベル 3

神経生理現象の面では「快適レベル2」と同様に報酬 系の神経回路が刺激される状態だが、生体を安定へと引 き戻したり種族維持のための行動誘発を目的とする「快 適レベル2」と違って、快そのものを目的として報酬系

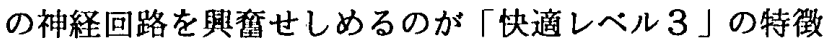

である。たとえば人は、渴きとは無関係に酩酊のために 酒を飲み、䌘殖とは別に楽しみのために性行動にふけり、 美食を求め:さらに空間や時間を「快楽」「悦楽」に変 える芸術的な行動を広笧に展開する。

座り心地は楽ではなくとも権力の象徵を目的化した 「王者の椅子」は快楽（権力欲の充足）のための椅子だ と言える。一方、苦しい登山の未に頂きで座る岩もまた 快楽の椅子の一種であり、苦を快に変える人間的喜びの 例である。また、岡本太郎に「座ることを拒否する椅子」 という作品がある。座面に笑起があって座ると痛いとい う代物だが、これなどす、椅子は座るものという常識を 拒否し想像力を喚起する点で、高度な精神レベル（芸術 レベル）での「快楽・悦楽」の椅子と呼ぶことができる。

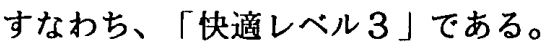

これらはほんの一例だが、人間の自由と想像力に関係 している点で共通しており、そこに「快適レベル3」の 特徴がある。したがって、生体を自動制御（ホメオスタ シス）のオートマトンに喻えることができるのに対して、

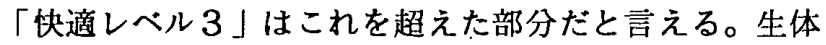
や種族の維持という生物学的目的から自由な、快のため の快であるこの領域は、文化の苗床でもあり、人間の大 きな特徵として重要である。

ところで、「快適レベル2」にもう一度注目してみる と、空腹時の食事がうまく、炎天下の水がうまいように、 「快適レベル2」は「不快レベル1」との対比で生じる のが通例である。よく言われるように、「苦労が大きけ ればそれだけ報われるものも大きい」というわけである。 人間はこのことを利用して快を創出し、あるいは拡大す

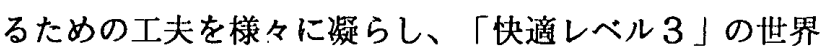
を幅広く展開している。そのために快適性の問題が複雑 な様相をなす場合があるが、「快適レベル2」の上位に

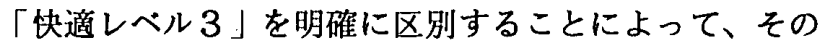
複雑さを解き明かし、かなり整理をゆきとどかせること ができるだろう。

たとえば、露天風呂で寒気と温湯の刺激を繰り返すの

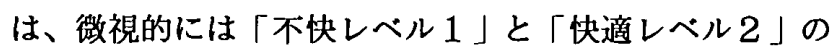
絽り返しだが、全体としては「快適レベル3」のための、 露天風呂芸術と呼んであよいような演出がそこにあるこ とを見出すことができる、等である。注131

\section{○快適レベル 4}

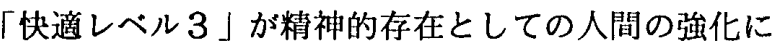
結びつく精神維持的性格をもつのに対して、このレベル は逆に人間の精神をも肉体をも破壊する傾向がある。

薬物については既に述へたたが、今日の消費社会を支え る消費者の際限のない物欲や刺激の強い娛楽への傾斜傾 向なとを見ると、そこにも一種の耿溺性が認められ、快 のための快でありながら、それが自らを高める方向とは 逆行する性格が働いている場合も多い。その意味で、蒋 
物現象と似たところがある。この場合には快中权の受容 体が受け入れるのは（合鍵ではなく）正規の伝達物質で あるから薬物の場合とは生理現象の構造が違うが、おな じように破壊型快楽と見ることができるので、このレべ ルにまとめるのが便利である。

\section{4. 考察}

（1）快適の状況依存性、個人差

特定の物理的条件が常に一定の快・不快を感じさせる とは限らない。時により人によって感じ方が大いに異な る場合がある。それはホメオスタシスの原理からして当 然のことと言える。たとえば、体が冷えすぎるのは危険

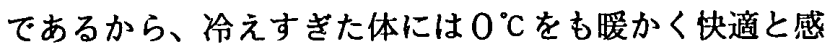
じるという報酬を与えてそちらの方向を求めるように仕 向け、暑すぎもまた危険であるから、熱しすぎた体には $30^{\circ} \mathrm{C}$ の温度を涼しくて快適と感じる報酬を与えて、そ れを求めるよう仕向ける。しかし体温が正常に戻ってく ると、 $0{ }^{\circ} \mathrm{Cは}$ 当然寒いのでもっと高温を快適と感じるよ うに報酬が変わらなければならないし、逆に $30^{\circ} \mathrm{C}$ は署 いので、より低温を快適と感じるように変わるのである。 それが生体の仕組みである。快・不快の個人差について も、生体そのものの差に由来するものであり、当然とい える。また、学習の違いによる個人差も考えられる。

「快適レベル3」については、人の感受性が大きく影 響するものと思われる。「王者の椅子」を快楽と感じる 感受性を誰もが持っているとは限らないし、芸術作品の もたらす感動を誰もが公平に体験するとは限らない、等 である。

このように快適の状沿依存性、個人差は明白だが、特 定の集団内での共通部分も大きいと考えられるので、そ れについて明らかにするための研究も重要である。また、 状況や個人差対応は計画の中で操作を個人にまかせる等 の方法で対処するのがよいとする見解があるのは妥当で ある。注 141

（2）感覚的快適·感性的快適

快・不快を生起させる刺激にはシグナル型とシンボル 型があることは既に述べたが、これに対応する快・不快 を、「感覚的」な快・不快と「感性的」な快・不快と呼 ぶこともできる。注151

冷えた体を湯につけた時の生き返るような快感は感覚 的レベルの快であるが、露天風呂のように風情や風流と いった文化的しっらえの中で味わう湯の心地よさには、 単なる感覚を超えて、日本人の心にフィットする感性的 レベルの快適がある。

感性を特色つけているのは心と文化だといえる。心の 機能とは、感覚的な原始感情を評価し、それに喜びや悲 しみといった人間的価值の枠組みを課すことである。そ
れは、文化の教条に依存するところが大きく、したがっ て心は文化によって型とられているとも言える。結局、 感性は文化によって特色つけられるところが大きい。感 性の問題が人種・民族によって相体的であるのはそのた めであり、快・不快に関しても相対性の観点は不可欠で ある。田中直子は地域文化の特殊性について、一般的に は不快とみなされるような音であっても、その空間や地 域のアイデンティティを支え、その場らしさを表出する 役割を担っているものは意外と多く、注16)こうした空間 や地域の独自性に応じた音の文化的伍值が大切なことを 述べている。

もちろん生体の差に由来する個人差もあって、快・不 快には(1)生体レベル、(2)学習による個人差、(3)文化レペ ルによる差があることになり、「感覚的」は(1)に相当し、 「感性的」には(2)(3)含まれる。しかし、個人差は千差 万別であるので、操作的にものを考えるときには対象と しにくく、より基本的な文化レベルが重要となるのであ る。

「感覚的」（生体レベル）と「感性的」（文化レベル） 法15)はそれぞれ伝達性を供えているが、その性格は異な る。前者は遺伝であって、遺伝子 gene が伝達される。 一方、文化レベルでは特定の集団内に存在する文化的な 伝達子が考えられ、ドーキンス等はこれを meme（ミー ム) と呼ふ。201

快・不快の感性的レベルが meme型 であるということ は、特定の集団によって共有、伝達される快・不快の型 があるということであり、このことは脳の可塑性と関係 している。つまり、一定の刺激に反応し、快系（あるい は不快系）の伝達物質を放散せしめる神経系の仕組みが、 ある共通の文化圈に属する人には後天的に新皮質の中に 形成されていくのである。その時の刺激はシンボル型の 刺激と言うわけである。快であ不快でもない安定状態も、 可塑性の中で自ずと定まってくる。こうした事情によっ て、人の快適には文化と心が重要な役割を演じているの である。

（3）快・不快のコード化とコード違反

gene が全人類に共通しているとは限らない。気候条 件等に由来する民族差等が認められる。例えば、瞳の色 の違いは光への反応を異なったものとしている。したが って、 gene も meme と同じく特定の集団内での共通性 だと言える。いずれにしろ、快・不快とそれをもたらす 刺激の関係は集団内で瞡範化されている、つまりコード 化されている。

しかし、快楽・悦楽にはむしろコード違反であると考 えられるケースが多い。とりわけ、感性的な快楽・悦楽 はそうである。

感性的な快楽・悦楽は一種の感動だと言えるが、それ は文化規範によって抑え込まれた本能の活力が、文化の 
秩序を崩して漏れ出る経験であるとも言える。文化の枠 組みの中でいわば不自然に生きることを運命つけられた 人間には、この種の心の活性化が不可欠なようである。 伝統的な祭は、そのための社会的な仕掛であったといわ れる。

芸術作品が強い感動をもたらすのも、規範をつき崩す 革新性が感性の新しい局面を開いてくれる場合に限られ る。伝統的、安定的な美は「快適レベル1」であるが、 ドーパミン類の活発な放散を経験させてくれるのは、こ うしたコード化された美に対する違反に限られると言え そうである。今後の研究が期待される。

（4）快適性の今日的課題

快適を技術的に一面化する傾向や、商品の付加価值と

して快適を商品化する傾向がある。

問題は、快適を全て技術で解決できるとする幻想を生 むことであり、快適は買えるものだという思い違いがま かり通ることである。そのような部分はあるにしても、 その䇺囲は限られるはずである。にもかかわらず、それ がすへてであるかのように見なされかねない危うさが現 代にはある。

例えば、ファジーや1/fゆらぎが間的技術のうた い文句とされている場合があるが、れらの技術に可能 なのはせいぜい「快適レベル1」を安定化できるかどう かの程度であろう。現状てはをれも怪しい。もちろん、 高度な制御技術の開発によって「快適レベル1」あるい

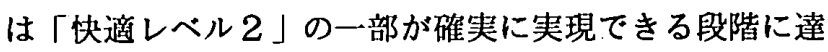
することは想定しておく必要があろう。しかし、それで 快適はすへてよしと考えてはならない。快適技術にうっ つを拔かして、人間にとって最も大切な快適は「快適し ベル 3 」にあることを忘れると、人間は技術の成となり、 プログラムから一歩も抜け出せない奴隷状態に陷ってし まう。人の快適さの追求には際限のない面がある。人工 環境下の生活に慣れると、人はさらに高度な技術に頼ろ うとする。それが、生体としての安定レベルを超えてい てもである。例えば、冷房病は、このような一種の奴隷 状態が原因しているように思われるのである。一方、人 は快楽の虜にもなりやすいので、快適の商品化が進むと、 いたずらな享楽主義の「快適レベル4」へと飛び越えて しまうことも㣰念される。

人間は、「快適レペル1」ないし「快適レペル2」に

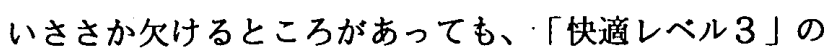
うちに充実を見いだせる限り豊かだ。逆の場合には貧し い。

また、「快適レベル 3」を忘れた技術的快適観に立つ 限り、技術への依存の度合いを深め続けるほかなく、そ のためのエネルギーを考えるならば、最近の地球温䁔化 問題と快適は完全に対立関係にならざるを得ない。見方 をちょっとずらして、「快適レベル3」を中心にすえた
精神的快適観を打ち立てることができれば、温暖化対策 と快適の両立がはかれ、人間は一段と心豊かになるとい うストーリーも不可能ではなくなる。

（5）快適性を測ることの可能性

さまざまの脳内の現象を定量的に捉える方法が進歩し ている。例えば、脳内の血流量や電気的反応の状況の測 定法として、最近、PETやMR I なとの非侵熋的画像

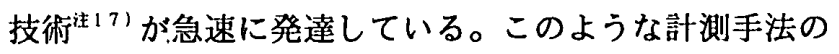
進歩は、先に述べた快・不快物質の放散状況を数値的に 把握し、快適さの水準を計測によって確認することの可 能性を予見させる。

従来のいわゆる官能評価は、被験者の主観評価に基つ くものであった。 ${ }^{i 18)}$ 主観による評価は客観化が難しく、 官能評価と生理応答注191 を対応させて、快・不快の状況 を捉える方法が用いられることが多い。しかし、現状の 生理応答の測定精度は、快・不快の違いが判別できるか とうかの程度に過ぎない。一方、何らかの方法でドーパ ミン類の放散を精度よく測定できれば、快適さの水準を 測ることも夢ではなくなる。

PETやMR I なとの新しい测定法は、ドーパミンと そのリセプターの活動状況を詳細に把握することができ る可能性を秘めた手段の一つと考えられる。将来、時間 的・空間的な分解能が飛躍的に向上すれば、快適さの測 定が現実のものとなるかもしれない。少なくとも、快適 レベル 1 と快適レベル2、3とでは、ドーパミン系等の 伝達物質の放散レベルが大きく異なることが予想され、 その違いが判別できるようになる可能性は高い。

\section{5.まとめ}

快適性の生理学的な基礎に基ついて、快・不快の諸水 準を「快適」「不快」のレペルとして統一的に整理した。 あわせて、神経生理現象との関係を併記し、さらに、感 覚的な快と感性的な快の区別およびその特性を、快・不 快の諸水準に対応させて表現した。

このような関係付けや対応を一元的に整理し明確にす ることによって、各々の水準の内容・位置つけや相互関 係が鮮明となり、さまさまの水準の快・不快の意味合い を明暸に表せるようになった。世の中に汇濫する様々な 「快適」の論議も、この構造に当てはめることではっき りとした意味付けが可能となるでなろう。

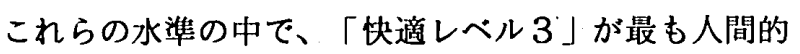
に重要な水準であることは本諭中で度々述へた通りであ る。この水準は、デルト以来二元的対立にあった精神 と肉体の問題を、一元的に調和するものとして考える上 であ、矛盾的存在でありながら協調して生命のホメオス タシス維持に值く心と体の有りょうを理解する上でも重 要である。 
また、本論では、快適の技術化の限界についても若干 の考察を加えた。すなわち、快適化の技術は「快適レへ ル1」の実現の手段に過ぎない、あるいは、「快適レベ ル2」の一部を担えるに過ぎないことを示した。このこ とは、快適のすへててを技術で実現でき、また、買うこと ができるとする今日的な幻想を打ち破り、人間的な快の 存在とその意義を明確に示す上で重要である。

なお、いくつか仮定した部分 (シンボル型快・不快の 脳内メカニズム等) については、その検証を神経生理学 の進展に待つ必要がある。それらの研究の進展をにらみ ながら建筑分野での快適研究を進めることの意義は大き いと考え、ひとつの仮説として本論を公表する。快適性 の構造に関する本論の提案が大方の批判的検討に供され、 快適性研究の前進に資することを期待するものである。

\section{く謝辞〉本論をまとめるに当たって、篠原修（東大工学} 部)、久野覚 (名大工学部)、符原正美（当時製品科学 研究所、現生命工学工業技術研究所) 、松原斎樹 (京都 府立大生活科学部)、岩崎庸男（筑波大心理学系）なら びに加藤力（京都工繊大工学部）の各氏に貴重な示唆を、 宮崎良文氏（森林総研）には多数の関連資料の提供を賜 った。ここに、記して感謝の意を表する。また、この研 究は建築研究所のプロジェクトとして実施されたもので あり、筆者ら以外の研究者の労屯多とした。併せて感謝 の意を表する。

なお、本論文は、1994 年度日本建築学会大会にお いて発表した論文（文献 1））、および、建築研究所平 成 4 年度研究報告書「快適性の評価構造に関する研究」

（平成 5 年 3 月）の一部を基に、追加・修正を行ってま とめたものである。

注)

1)快通とは、広辟苑によれば「ぐあいがよくて、匃持ちのよいこと」とあるが、

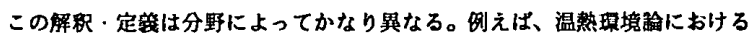

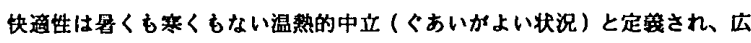

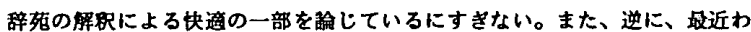
が国で块通と同㟴に用いられるアメニティは、本来都市計画の分野で包括的 な非常に大きな概念として用いられてきたものである。これら快送研究の現 状については、文塥 2 )に群しい。

2 ) 不块の除去を意味し、くあいのよい状況を表す「消楆的な快通」(英語ではC0

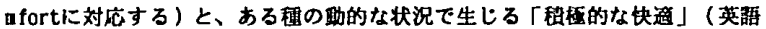
ではPleasantness）の2つの本檠に分けて快道を論しることが多くなされる。 しかしながら、各々の解粉は研究者によってあるいは分野によって微如に異

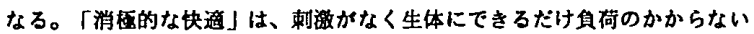

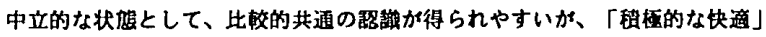

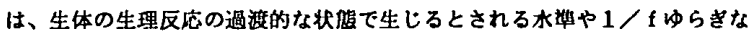
との理境の变娌栍と関保付けられるなと、多栐な提え万があり、また、その

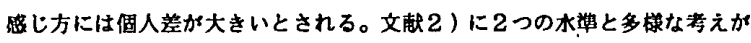
あることが紹介されている。その他、文嗝 3 )，２3），24），25）。 26)なと器。

3)一般に生物には、外部理境の変化に対し生体の内部境（器目・紐胞を生活さ

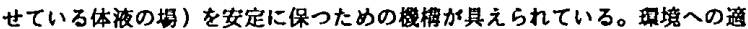

応や生命維持のために学まれる、そのような動的な平衙炏股（及び平衡を保

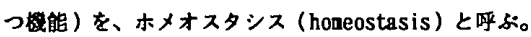

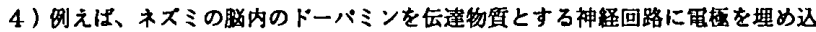
み、ベタルを踏むと电流が流杖ようにしておくと、ネスミはしきりとべダ ルを踏み、かたわらの食物や子ネスミをし碩みすに留中になる。

5 ) 例えは、、西欧の音楽と日本の音楽ではリズムのパターンに大きな䦽いがあるが、 それそれのバターンの特性か、西欧人にとっての快、日本人にとっての蚗と して意味ふけられてきた。

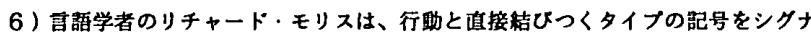
ルと呼ひ、シタナルの代替をする記号をシンボルと呼んだ。一般に動物はシ タナルの世界に生きているか、言語を用い、想像力を駅使する人間の世界は、

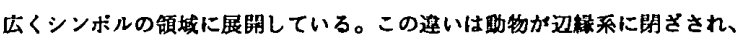
人間が就度な新皮質を有することに対応する。ここでは辺椂系型の刺澈をシ クナル型、新皮筫型の刺激をシンボル型と呼んで、モリスの用吘の転用を图 った。

7 ) シクナル型、シンボル型を生理的、心理的と呼んですよいが、生理的快通、心

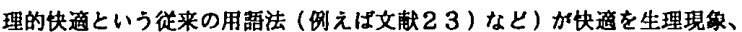
心理現象に分けているのとは明磪圤区別が必要。快通現象としてはいずれも 神経回路の興番という神経生理学的现象である、とするのが本論の立埸であ

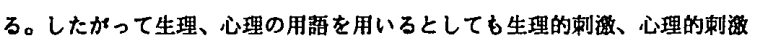
（あるいは情報の生理的处理レベル、心理的处理レベル）の意味においてで ある。

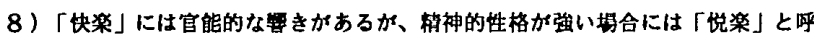
ふのが道切な場合もあるので両者を使い分けるのがよい。

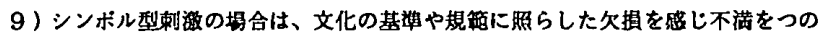

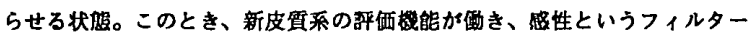
が機能している。胓価の基凖には個人差や文化差が大きく、同じ乱雑さでも、 人によって象じ方は同じではない。

10 ) 集合住宅、特に高酋住宅は高虫居住になりやすく、各住戸は画一的て、、住空

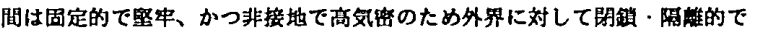
ある。このような空間的特性か、居住者に日常的なトラブルや心理的な閉銷

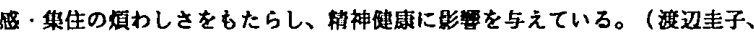

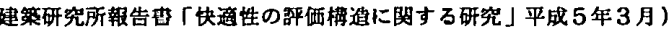

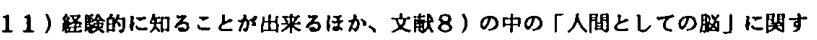
万范述等加ら推測可能である。

12）２（1）に述べたアメとム千のうち、アメに相当するものである。

13 ) 久野觉の示悛による。文献 13 ) より。

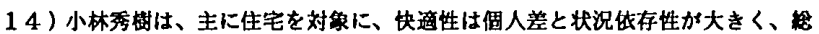

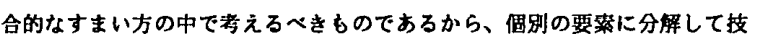

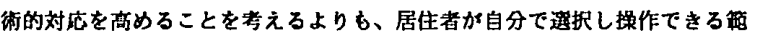
囲を払大する「対話」型の計画が更要であると述へている。このことには、 操作される個人よりも操作する個人という能野栍の回復の意味合いも边めら れている。

15 ) 前者は生体レべル、後者は文化レヘルと孝えられるので、心や文化の方向に 研究的議論を発展させる上で、このように用䈃を言い替えておくのは便利で あろう。ここで感性とは、文化のフィルターを通した情楮を意味する。

16)例えば、神田地城（東京）では、本のカバーを作るときのガッチャンガッチ ヤンという大きな機娀音や印剧機の音なと、住民や神田に関わりの深い人で なければ「不蚗」と判断するような耳唺りな音む、「本の町神田」の音とし て好意的に受け留められている。(因中直子、文嗝 14 ) )

17 ) PET (Positron Enission Tonography) PMR I (Magnetic Resonance Inaging；核础気共嗅イメーシンク)なとの非侵取的画佛技術は、ニューロン

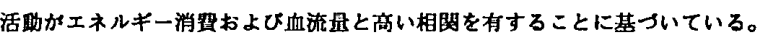
すなわち、訤内の局所血流盘の変化から、解神活野の状況を䏚の解剖学的な 地图上に描こうとするものである。しかしながら、その解像力はまだ慙く、 また、時間分谓能も神経活娌のスピードと比へるとずっと低いのか現状であ

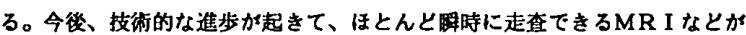
出現すれば、眨の神経回路かいかにして神神活娌を引き起こすのか、といっ

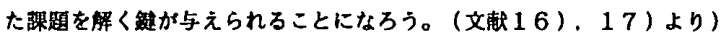

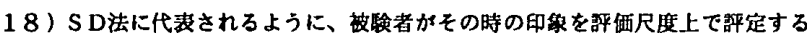

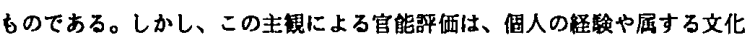
あるいはその時々の気分によっても異なり、客㙕化が難しい。

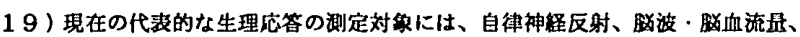

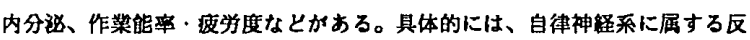




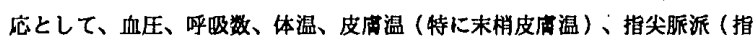

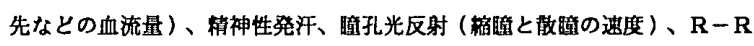
間隔 (心電图のビーク間隔の然化)、なとがある。脑波については、波や 波なとが中权神経系におけ万変化の呼価に用いられる。内分站ては、ス卜 レスホルモン(アトレレナリン、ノルアドレナリン、コルチソール筞)なとか

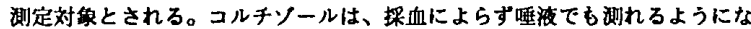
ク、ストレス状船の評洒に用いられるようになった。作業能率の简易な测定 法として文字消去法 (一定時間内に特定の文字のみを消去する)なと、疲学 度の测定法としてフリッカー组なと、がある。(文献 15 )による)

\section{〈参考文献〉}

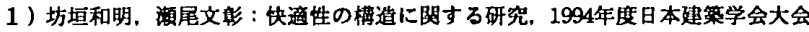
学術䫓演梗概集 D 理境工学. pp $1169 \sim 1170,1994.9$

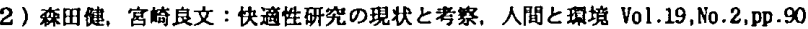
$\sim 98,1993$

3) 坊垣和明：䅡極的な快の策件. 住サイエンス Vol.10，pp33〜38. 1989.9

4) 高木他編：腅の生体揰告系，東大出版会，1986.7.20

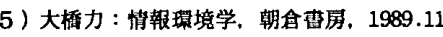

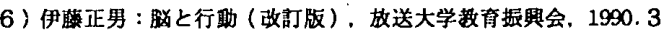

7 ) 堀哲郎：胼と情動，共立出肘，1991.9

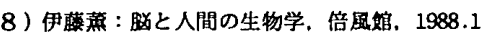

9 ) S.H.Snyder：㮸と薬物，東京化学同人、1990.11

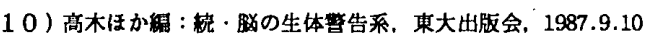

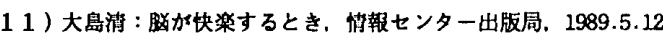

12 ）カラット：バイオサイコロジー1．2．3．，サイエンス社

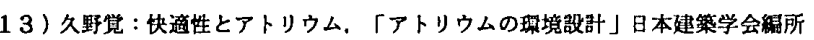
收, 1994

14 ）田中直子：音理境とアザイン、「都市とア゙ザイン」所收，電通，1992.5.1

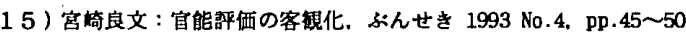

16 ) G.D.Fischbach : 睎と心、日経サイエンス1992年11月号。pp.12〜24

17 ) U.E.Raichle：心をみる画像技術，日経サイエンス1994年6月号, pp.58〜67

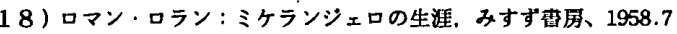

19 ) 羽仁五郎：ミケランジェ口，岩波新苏、1939.3

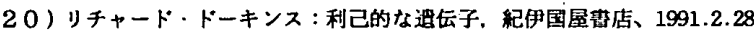

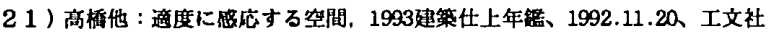

22 ) J.Davis : 快楽物劦エンドルフィン，青士社、1989.6.10

23 ）宫田紀元：住理境の快通性とPOE. 住生活No.184、1990.1

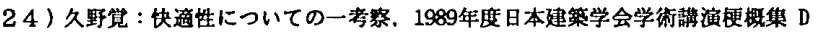
㻴境工学, pp71-72、1989.10

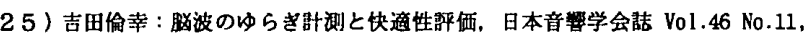
pp914 919, 1990

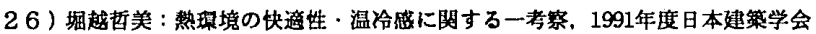

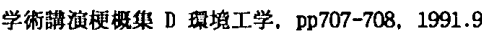

（1994年 9 月27日原稿受理，1995年 6 月 6 日採用決定） 